\title{
100 years
}

of a scientific and professional journal

Ročník I.

\section{BRATISLAVSKÉ LEKÁRSKE LISTY \\ Orgán bratislavskej univerzity \\ vydávaný Spolkom československých lekárov v Bratislave}

Redakčná rada:

Prof. Brdlík, Prof. Hynek, Dr. Izák, Prof. Kadlický, podpluk. Dr. Kolačný, Prof. Kostlivý, Prof. Müller, Prof. Mysliveček, Prof. Netoušek, Prof. Polák, Prof. Prokop, Prof. Reinsberg, Prof. Růžička, Prof. Spilka, Dr. Šaršún, Prim. Dr. Uram

Hlavní redaktori:

Prof. Dr. K. Hynek, Prof. Dr. M. Netoušek, Dr. A. Měska.

\section{BRATISLAVA MEDICAL JOURNAL}




\section{Úvodem}

Pozvolna sice, ale ustavičně blížíme se $\mathrm{k}$ svému cíli, $\mathrm{k}$ vybudování lékařského vědeckého života na Slovensku a tím i k dobudování jeho v celé republice. Stojíme dnes vydávajíce prvé číslo našeho časopisu, u třetí jeho etapy. Před několika dny (21. záŕí) byla tomu dvě léta, co jsme zahájili v Bratislavě svoji činnost, po necelém roce jsme mohli založit spolek československých lékařů a konati týdenní vědecké schůze a dnes předkládáme naší odborné veřejnosti další výsledky své vědecké a organizační práce. Plníme tak svoji povinnost $\mathrm{k}$ československé vědě a $\mathrm{k}$ jejímu lékařstvu. Nechceme soutěžiti, naši snahou jest vzájemně se doplňovati a rozšriřiti fórum našeho lékařského tisku. Zveme proto všechny kolegy i přátele ke spolupráci a bude nám vítán každý vážný příspěvek.

Redakce.

\section{Pripomenutie minulosti}

Časopis Bratislava Medical Journal patrí do skupiny tých časopisov, ktoré ani s pribúdajúcimi rokmi a so zdokonal'ovaním všetkého nestrácajú význam, teda ani vlastnú podstatu. Hlboký záujem, rešpekt a vieru, že zlé časy pominú, sa premieta aj do toho, že tento časopis ani v čase 2 . svetovej vojny neprestal vychádzat'. Uplynulo 100 rokov nepretržitého vydávania časopisu. $\mathrm{V}$ tomto smere je to mimoriadne kontinuum viac ako európskeho rozmeru. Časopis dosahoval ciele moderného vedeckého periodika od jeho vzniku. Rukopisy boli publikované v slovenčine a češtine $\mathrm{s}$ abstraktmi $\mathrm{v}$ jazyku anglickom, nemeckom, francúzskom a ruskom. Od roku 2002 vychádza časopis v anglickom jazyku. Všetky čísla sú dostupné vo svetovej databáze a v našej redakcii. Časopis je od 1. čísla z roku 1921 aj v elektronickej forme.

Všetky zväzky a ročníky sú $\mathrm{v}$ prvotriednom stave a sú profesionálne zviazané a uložené na Lekárskej fakulte UK. Časopis je súčast'ou svetovej databázy Web of Science a d'alších informačných zdrojov (PubMed, Scopus a pod.). V „živej forme“ sú kompletné texty dostupné vo Web of Science a na www.elis.sk.

Od roku 1921 sú všetky čísla súčast'ou najprestížnejšej svetovej databázy - Web of Science. Časopis Bratislava Medical Journal je medzinárodne rešpektovaným časopisom. Evaluácia časopisu vo Web of Science je dostupná s „adresou“ bratisl lek listy od prvého čísla roku 1921, odteraz 
aj s adresou bratisl med j. V týchto zdrojoch je dostupná evaluácia citovanosti a impakt faktor časopisu.

$\mathrm{V}$ minulom roku časopis prekročil hranicu impakt faktora s hodnotou 1,240, čím sa zaradil medzi svetové vedecké časopisy. Je to aj nespochybnitel'ný dôkaz pre ašpiráciu časopisu na zaradenie do kultúrneho dedičstva UNESCO aj z celosvetového hl'adiska v kontinuu nepretržitého 100-ročného vydávania. Kontinuum časopisu je deskripciou vedeckých udalostí, pokroku v medicíne, ale aj zdrojom mimoriadne cenných informácií vedeckej povahy. V časopise sú publikované vedecké štúdie, ktoré poskytujú dokonalý obraz nielen z medicínskej a vedeckej stránky, ale aj informácie týkajúce sa úrovne medicíny. Napríklad informácie o prvej transplantácii srdca v Československu, ale aj výskyt tuberkulózy a mnoho informácií z vedeckých diskusií. Tieto informácie sú mimoriadne významné aj preto, že boli koncipované ako vedecké štúdie bez kompilácie o politickej situácii.

Z národného hl'adiska je časopis pýchou, lebo ide o zverejnenie aj nepriaznivých výsledkov pri epidémiách, alebo pri výskyte syfilisu, tuberkulózy a d'alších chorôb. Nie na poslednom mieste poskytuje informácie aj o príčinách najčastejších úmrtí. V premenách času sa nám podarilo zachovat' kontinuitu časopisu, ktorý rešpektuje pôvodné ciele aj napriek spoločenským, politickým i názorovým vplyvom. Ďalšie roky určite zvýšia záujem o komparáciu, o analýzy porúch v l’udskom organizme, ktoré sa v ére bez antibiotík, bez lokálnych anestetík mohli zamerat' iba na ovplyvnenie symptómov chorôb bez možnosti kauzálnej liečby. Význam časopisu nepochybne dosahuje celosvetovú úroveň.

Výnimočnost' časopisu je aj v dokonalom obraze toho, čo súviselo v minulosti s medicínou. V predchádzajúcich rokoch sa v časopise publikovali zápisnice z rokovania Spolku slovenských lekárov. Takto sú zachytené medicínske problémy súvisle desiatky rokov. Okrem striktne odborných informácí́ časopis je aj obrazom vývoja odbornej lekárskej spisby. Raritnost' vidíme aj v tom, že časopis zachytáva obraz stredoeurópskej medicíny v jej vývoji. Niekedy vidiet' aj prienik spoločenských zmien, ktoré boli násilne inkorporované do časopisu.

Informácie o tomto časopise publikoval Oxford Academic Press a členom vedeckého kolégia časopisu bol od roku 2002 nositel' Nobelovej ceny F. Lauterbur až do jeho odchodu do večnosti Vesmíru. Dávnejšie sme korešpondovali s niekol'kými nositel'mi Nobelovej ceny.

Bratislava Medical Journal - Bratislavské lekárske listy dosahujú ciele moderného vedeckého časopisu od jeho vzniku. Myslíme si, že 
z hl'adiska redakcie sa nám podarilo dosiahnut' najvyššie méty, po ktorých túžia mnohé vedecké časopisy. Pracovníci redakcie spolu s d’alšími pracovníkmi vydali knižky „O vedeckom bádaní v medicíne“, aby sme priblížili podstatu, híbku a zmysel vedeckého bádania a intelektuálneho napredovania. Rešpektujeme, že aj evaluácia univerzít je postavená na hodnotení, pri ktorom sa dve tretiny parametrov týkajú činností spojených s vedeckým bádaním a akceptovaním vedeckých výsledkov vo svetovom meradle. Knižky sme vydali aj v anglickej verzii. Do redakcie dostávame rukopisy, ktorých počet 20-násobne prevyšuje počet rukopisov, ktoré môžeme $\mathrm{v}$ stanovenom rozsahu časopisu uverejnit'.

Celosvetovo sa teraz aj zložité medicínske výkony nahrádzajú robotizáciou a technické postupy využívajú modernú výpočtovú techniku. Najcennejšou v celosvetovom meradle však ostáva kreativita a intelektuálna činnost' $\mathrm{v}$ špecializovaných odboroch. Medicína $\mathrm{k}$ nim určite patrí. $\mathrm{Z}$ uvedených informácií je zrejmé, že časopis je mimoriadnou súčast'ou intelektuálneho potenciálu svetových spoločenstiev, vedy a vzdelávania. Okrem toho je aj dôkazom pozície časopisu vo vede, $v$ intelektuálnej oblasti a vo sfére kultúrneho dedičstva. Na základe deklarácie Národnej rady SR sú Bratislavské lekárske listy kultúrnym a vedeckým dedičstvom Slovenskej republiky. Uchádzame sa o zápis tohto nášho časopisu do Medzinárodného programu UNESCO „Pamät' sveta“. Bolo by to oficiálnym uznaním významu tohto vedeckého časopisu.

Osobne želáme všetkým pokračovatel’om v redaktorskej práci nielen úspech, ale aj nadšenie a radost' z prieniku do podstaty zložitostí, ktorých detekcia nie je na blízku dvoch, či troch storočí. Pravda s podmienkou, že l'udstvo uchráni tento svet a vedu a múdrost' bude považovat' za cestu vyššie pre úžitok všetkých.

Ivan Hulín

Helena Bernadičová 


\section{0 years}

of a scientific and professional journal

\section{Bratislava Medical Journal}

Bratislava Medical Journal is published continuously since 1921 year

The main editors at its inception were:

Prof. Dr. K. Hynek, Prof. Dr. M. Netoušek, Dr. A. Měska.

The members of the editorial board were:

Prof. Brdlík, Prof. Hynek, Dr. Izák, Prof. Kadlický, podpluk. Dr. Kolačný,

Prof. Kostlivý, Prof. Müller, Prof. Mysliveček, Prof. Netoušek, Prof. Polák, Prof. Prokop, Prof. Reinsberg, Prof. Rủžička, Prof. Spilka, Dr. Šaršún, Prim. Dr. Uram

On the first page, the editors defined the main goal of the journal with these words.

\section{Introduction}

Slowly, but constantly, we are approaching our goal, to build a medical scientific life in Slovakia and thus to complete it throughout the country. We stand today publishing the first issue of our magazine, at the third stage. A few days ago (September 21, it was two years since we started our activities in Bratislava, after less than a year we were able to establish an association of Czechoslovak doctors and hold weekly scientific meetings, and today we present our results of our scientific and organizational work to our professional public. We do not want to compete, our aim is to complement each other and expand the forum of our medical press, so we invite all colleagues and friends to cooperate and we will welcome any serious contributions.

Editorial staff. 


\section{A reminder of the past}

The Bratislava Medical Journal belongs to the group of those journals which, even with the coming years and with the improvement of everything, do not lose their significance, ie not their own essence. The deep interest, respect and belief that bad times will pass is also reflected in the fact that this magazine did not stop publishing even during the Second World War. Its publication has not been interrupted. 100 years of continuous magazine publishing have passed. In this respect, it is an extraordinary continuum of more than a European dimension. The journal has achieved the goals of modern scientific periodicals since its inception. The manuscripts were published in Slovak and Czech with abstracts in English, German, French and Russian. The magazine has been published in English since 2002. All issues are available in the world database and in our editorial office. The magazine has been in electronic form since the first issue of 1921.

All volumes and volumes are in first-class condition and are professionally bound and stored at the Medical Faculty of Charles University. The journal is part of the world database Web of Science and other information sources (PubMed, Scopus, etc.). Complete texts are available in ,live form“ in the Web of Science and at www.elis.sk.

Since 1921, all numbers have been part of the world's most prestigious database - the Web of Science. The Bratislava Medical Journal is an internationally respected journal. The evaluation of the journal in Web of Science is available with the ,address" of bratisllek letters from the first issue in 1921 until now also with the address of bratisl med $\mathrm{j}$. The evaluation of the citation and the impact factor of the journal are available in these sources.

Last year, the journal crossed the ,impact factor“ of 1,240, making it one of the world's scientific journals. It is also indisputable evidence for the aspiration of the magazine for inclusion in the UNESCO cultural heritage, even from a global point of view in the continuum of a continuous 100 -year publication. The continuum of the journal is a description of scientific events, advances in medicine, but also a source of extremely valuable information of a scientific nature. The journal publishes scientific studies that provide a perfect picture not only of the medical and scientific side, but also information about the level of medicine. For example, information about the first heart transplant in Czechoslovakia, but also the occurrence of tuberculosis and a lot of information from scientific discussions. This information is particularly 
important because it was conceived as a scientific study without compiling on the political situation.

From a national point of view, the magazine is proud, because it is also about publishing adverse results in epidemics or in the presence of syphilis, tuberculosis and other diseases. Last but not least, it also provides information on the causes of the most common deaths. In the changes of time, we managed to maintain the continuity of the magazine, which respects the original goals despite social, political and ideological influences. Next years they will certainly increase the interest in comparison, in the analysis of disorders in the human body, which in the era without antibiotics, without local anesthetics could focus only on influencing the symptoms of diseases without the possibility of causal treatment. The importance of the magazine undoubtedly reaches a global level.

The uniqueness of the journal is also in a perfect picture of what was related to medicine in the past. In previous years, the minutes of the meeting of the Association of Slovak Physicians were published in the journal. In this way, medical problems have been captured for decades. In addition to strictly professional information, the journal is also a picture of the development of professional medical records. We also see a rarity in the fact that the magazine captures the image of Central European medicine in its development. Sometimes the penetration of social changes that have been forcibly incorporated into the magazine can also be seen.

Information about this journal was published by the Oxford Academic Press and a member of the scientific board of the journal was Nobel Prize winner F. Lauterbur from 2002 until his departure into the eternity of the Universe. We have previously corresponded with several Nobel Prize winners.

Bratislava Medical Journal - Bratislava Medical Journal has been achieving the goals of a modern scientific journal since its inception. We think that, from the editorial point of view, we have managed to reach the highest goals that many scientific journals long for. The editorial staff, together with other staff, have published books „On Scientific Research in Medicine“" in order to bring closer the essence, depth and meaning of scientific research and intellectual advancement. We respect that the evaluation of universities is also based on evaluation, in which two thirds of the parameters relate to activities related to scientific research and the acceptance of scientific results on a global scale. We have also published the books in the English version. We receive manuscripts in the editorial 
office, the number of which exceeds 20 times the number of manuscripts that we can publish in the specified scope of the journal.

Globally, even complex medical procedures are now being replaced by robotics, and technical procedures are using modern computer technology. However, creativity and intellectual activity in specialized fields remain the most valuable on a global scale. Medicine certainly belongs among them. From the above information, it is clear that the journal is an extraordinary part of the intellectual potential of the world's communities, science and education. In addition, it is proof of the journal's position in science, the intellectual field and the field of cultural heritage. Based on the declaration of the National Council of the Slovak Republic, the Bratislava Medical Papers are the cultural and scientific heritage of the Slovak Republic. We are applying for the registration of this magazine in the UNESCO International Program - „Memory of the World". It would be an official recognition of the importance of this scientific journal.

Personally, I wish all successors in editorial work not only success, but also a higher degree of enthusiasm and joy in penetrating the essence of complexities, the detection of which is not close to two or three centuries. Truth on the condition that humanity will save this world and will consider science and wisdom as a way higher for the benefit of all.

Ivan Hulin

Helena Bernadicova 